DR. INÊS CATRY (Orcid ID : 0000-0002-5593-5001)

Article type : Original Paper

Editor: Cardador, Laura

\title{
Combining stable isotope analysis and conventional techniques to improve knowledge of the diet of the European Roller Coracias garrulus
}

\author{
I. CATRY, ${ }^{1,2,3^{*}}$ A. SAMPAIO, ${ }^{4}$ M.C. SILVA, ${ }^{5}$ F. MOREIRA, ${ }^{1,3}$ A.M.A. FRANCO ${ }^{2} \&$ T. \\ CATRY $^{6}$
}

${ }^{1}$ Centro de Ecologia Aplicada 'Prof. Baeta Neves' and InBIO - Rede de Investigacão em Biodiversidade e Biologia Evolutiva, Instituto Superior de Agronomia, Universidade de Lisboa, Lisboa, Portugal

${ }^{2}$ School of Environmental Sciences, University of East Anglia, Norwich, UK

${ }^{3}$ REN Biodiversity Chair, CIBIO/InBIO - Rede de Investigacão em Biodiversidade e Biologia Evolutiva, Universidade do Porto, Vairão, Portugal

${ }^{4}$ Departamento de Biologia Animal, Faculdade de Ciências da Universidade de Lisboa, Lisboa, Portugal

${ }^{5}$ Centre for Ecology, Evolution and Environmental Changes, Faculdade de Ciências Universidade de Lisboa, Lisbon, Portugal

${ }^{6}$ Centro de Estudos do Ambiente e do Mar (CESAM), Departamento de Biologia Animal, Faculdade de Ciências da Universidade de Lisboa, Lisboa, Portugal

*Corresponding author: inescatry@ gmail.com

\section{Keywords}

Diet-assessment techniques; pellets; cameras; stable isotopic analysis; isotopic niche; Bayesian mixing models; dietary segregation

This article has been accepted for publication and undergone full peer review but has not been through the copyediting, typesetting, pagination and proofreading process, which may lead to differences between this version and the Version of Record. Please cite this article as doi: 10.1111/ibi.12625

This article is protected by copyright. All rights reserved. 
Diet studies are crucial for understanding the ecology and evolution of species, as well as for establishing appropriate conservation and management strategies. However, they remain methodologically challenging due to variation between seasons, sites, sexes or age groups and even variation between individuals. Due to method-specific characteristics and biases, a combination of existing techniques can overcome the inherent limitations of each technique and provide a more accurate and broad picture of species' food preferences. Here, we examine diet information obtained using three different assessment methods to better understand the trophic ecology of the European Roller Coracias garrulus, a species targeted by conservation measures in Europe. First, we analysed regurgitated pellets and video recordings to report the diet composition of adult and nestling Rollers, respectively. Secondly, we used stable isotope analysis (SIA) to investigate adult sexual diet segregation as well as to confirm the main findings regarding adult and nestling diets obtained through conventional methods. Based on the analysis of pellets, the diet of adult Rollers was dominated by Coleoptera, while camera images revealed that the diet of nestlings was dominated by Orthoptera, mainly grasshoppers and bush crickets. Blood isotopic signatures of adult and nestling Rollers confirmed the results obtained through pellet and video recording techniques. Of the three methods, pellet analysis contained the most comprehensive trophic information regarding the detectable prey spectrum and prey species contribution, and also provided basic diet information to inform the SIA. Our results also highlight the potential of SIA for assessing intra-specific variation in diet by sampling individuals of known age and sex, which is often unfeasible through conventional approaches. SIA analysis showed no differences in $\delta^{13} \mathrm{C}$ and $\delta^{15} \mathrm{~N}$ ratios of blood between males and females and a high degree of overlap amongst isotopic niches, suggesting no sex-specific partitioning in resource use. Overall, we showed that the combination of different methods could be used to gain new and clearer insights into avian trophic ecology that are essential for informing habitat management aiming to improve availability of foraging resources.

Diet studies are crucial to understand species trophic ecology and population dynamics, providing key knowledge for implementation of effective species-based management initiatives and conservation strategies (Morrison et al. 1990, Sutherland 2004, Marti et al. 2007, Catry et al. 2012). Nonetheless, diet assessment is difficult. The choice of the method depends on the questions being asked, and it needs to consider that diet varies across species, seasons, and between sites, sexes, or age groups and even between individuals (Sutherland 
2004). Several methods are frequently used to assess the diet of birds, each with specific advantages and drawbacks, which need to be considered when designing studies and interpreting results (Barret et al. 2007, Resano-Mayor et al. 2014, García-Salgado et al. 2015, Dicken et al. 2017).

Traditionally, avian diet studies have been conducted using techniques such as direct observations of foraging, and analyses of individual stomach contents, faecal droppings and regurgitated pellets (e.g. Nazaro \& Blendinger 2017, Wheelwright 1986, Donald et al. 2001, Catry et al. 2012). Despite its limitations (e.g. Redpath et al. 2001, Sutherland 2004, Marti et al. 2007), analysis of regurgitated pellets and images from video cameras are widespread techniques used to evaluate qualitative and quantitative composition of diets (e.g. Hounsome et al. 2004, Grémillet et al. 2006, Votier et al. 2007, Rodríguez et al. 2010, García-Salgado et al. 2015). In most cases, these conventional diet assessment methods do not permit withinspecies study of diet (e.g. intra-specific patterns of food allocation between sexes or between parents and their offspring; Forero et al. 2002, Catry et al. 2016a).

More recently, the use of stable isotopes, in particular of carbon $\left(\delta^{13} \mathrm{C}\right)$ and nitrogen $\left(\delta^{15} \mathrm{~N}\right)$, allowed a relevant advance in studies of avian trophic ecology (e.g. Bearhop et al. 2004, Alonso et al. 2012, Catry et al. 2016b). Stable isotope analysis (SIA) provides information on food sources that have been incorporated into an animal's tissues over time (Hobson \& Wassenaar 2008). The shift in isotope ratio between diet and consumer tissue is known as the trophic enrichment factor (TEF) and can be used in isotopic mixing models to quantify the relative contributions of isotopically distinct food sources to species' diet (Hobson \& Clark 1992, Inger et al. 2006). One of the main advantages of SIA is the opportunity to obtain data from particular individuals, allowing the comparison of food allocation, for example, between males and females or between age groups (e.g. Alonso et al. 2012, Catry et al. 2016a). However, prior knowledge of how stable-isotope ratios in consumer tissues are related to those in the diet (Hobson \& Clark 1992, Bond \& Diamond 2011) as well as of the isotopic signatures of prey are both required to interpret such differences (Hobson \& Clark 1992, Resano-Mayor et al. 2014). Additionally, to accurately estimate the contribution of different prey to a consumer's diet, prey must have distinct isotopic signatures and if all prey sources differ in only one dimension (i.e. one isotope) and the consumer's signature lies within their isotopic space, then the estimate will have low precision. Overall, given the specific limitations and bias of each diet assessment technique, 
several authors propose to integrate diet information obtained by several methods for appropriate evaluations of bird diet (Barret et al. 2007, Casper et al. 2007, Oehm et al. 2016, Oehm et al. 2017).

In this study, we combine traditional diet assessment techniques and SIA to assess the diet of the European Roller Coracias garrulus through the breeding period, in an extensive agricultural landscape in the Iberian Peninsula. The European Roller (hereafter Roller) is a migratory summer visitor to the Palaearctic region, which breeds throughout temperate, steppe and Mediterranean zones from northwest Africa to the western Himalayas (Cramp \& Simmons 1988). In Europe, the species has undergone rapid declines across its range and breeding populations are highly fragmented (Tucker \& Heath 1994, Samwald \& Štumberger 1997). One major cause of these declines is the loss of suitable habitat due to changing agricultural practices and increased insecticide use (Kovacs et al. 2008). Other critical threats include the conversion of permanent grassland to other land use, land abandonment and reduced management of meadows and pastures leading to the destruction of microhabitats for the prey of Rollers, mainly large invertebrates (Kovacs et al. 2008).

Whilst detailed knowledge on Roller conservation ecology is essential in developing effective management plans, key information on foraging habitat preferences and trophic ecology (e.g. diet variation between seasons, ages and sexes) is still incomplete (but see Avilés \& Parejo 1997, 2002, Catry et al. 2017a). The main aim of this study was to characterize the diet of both adult and nestling Rollers by (1) performing a comprehensive pellet analysis to characterize the diet composition of adults, (2) monitoring chick provisioning with video cameras to assess the diet of nestlings, (3) using stable isotope analysis (SIA) to investigate sexual diet segregation, (4) comparing main prey consumption estimates obtained from pellet and video analysis with results from isotopic mixing models in order to assess the overall agreement between these techniques and (5) discussing the flaws and strengths of each technique and their effectiveness in determining the diet of European Rollers.

\section{METHODS}

\section{Study area and data collection}

This study was carried out in the Castro Verde Special Protection Area (SPA), $37^{\circ} 41^{\prime} \mathrm{N}$, $8^{\circ} 05^{\prime} \mathrm{W}$, the main Portuguese area of cereal steppes, considered a stronghold for steppe bird conservation in Western Europe (BirdLife International 2004). Here, Rollers occupy cavities 
in ruins of abandoned farmhouses or artificial nesting structures (such as nest-boxes, clay pots or breeding walls) scattered in a treeless steppe landscape (Catry et al. 2017a). Breeding birds arrive from their African wintering areas in mid-April and typically lay three to six eggs in May; hatching occurs after 17 to 19 days, and chicks fledge at 25 to 30 days (Del Hoyo et al. 2001).

To study the diet of adult Rollers, 50 pellets were collected in 2013 and 34 in 2016 from 18 nesting sites. Some of these nesting sites (abandoned buildings or artificial breeding walls with many suitable nests) can hold up to four pairs of Rollers. Searches for pellets were conducted through weekly visits to nesting sites between mid-April and end of June, mostly during the incubation period. To avoid sampling old pellets, the area was cleared of pellets at each visit. All pellets collected were kept individually in plastic bags, labelled with date and local information, until further analysis. Pellets from the two breeding seasons were pooled to increase sample size and provide a broader view on the diet of adult Rollers. In addition, data from the two years cover a geographic area more comparable to that used for assessing chick diet.

To study the diet of nestlings, we used small video recording cameras (UNOTEC® SherLock Spy Camera; dimensions: $4.9 \times 3 \times 1 \mathrm{~cm}$ ) equipped with an external $250 \mathrm{mAh}$ lithium battery and with an 8 GB SD card providing ca. two-hour autonomy (unit cost $=35$ $€)$. Cameras were installed near nest entrances $(<1$ metre) to allow identification of prey items delivered to 2-25 day old chicks. We video recorded 19 nests between 2 June and 9 July 2016 at different times of day (mean \pm sd hours/nest $=3.9 \pm 2.47$, $\min =1.31$, $\max =$ 7.80). Nestlings also produce pellets, but these are trampled in the nest, making individual pellets impossible to analyse. Moreover, nests are used for consecutive years, often by different species, and prey remains accumulate, thus preventing prey identification for a specific year or species.

Blood sampling for SIA was carried out during the breeding season of 2016 (Table 1). Adults $(\mathrm{n}=35)$ and nestlings $>10$ days old $(\mathrm{n}=15)$ were caught in their nests between 16 May-30 June and 19 June-9 July, respectively. In order to investigate morphological sexual dimorphism in Rollers, adult birds were measured (wing length) and weighed and adult body condition (weight/wing) was estimated. Approximately $150 \mu \mathrm{l}$ of blood was collected from the brachial vein (Catry et al. 2016a), and a few drops were preserved in vials with Queen's Lysis Buffer (Longmire et al. 1997) for molecular sexing. The remaining blood was centrifuged for $10 \mathrm{~min}$ at $3400 \mathrm{rpm}$ within $3 \mathrm{~h}$ of collection, to separate the plasma from red blood cells (RBC). RBC samples were frozen before being further prepared for stable isotope 
analysis (plasma was not analysed). Carbon and nitrogen stable isotopes have a half-life of approximately 15 days in RBC (based on the allometric relationship between elemental turnover and body size; Hobson \& Wassenaar 2008), and presumably give information on diet composition for approximately that period before the sampling event. Accordingly, we sampled mainly the incubation period, although samples from adults captured within the first 15 days after first egg laid could still represent the mate-feeding period (more likely to reveal segregation between sexes, Catry et al. 2016a). Indeed, males also feed their mates during egg laying, which takes approximately one week for a mean clutch of 4-5 eggs. Assessing diet composition through SIA requires prior knowledge on the diet of the target species and isotopic signatures of consumed prey (Resano-Mayor et al. 2014). Thus, to characterize the main prey of Rollers (identified in pellets and video recordings) isotopically, we collected several potential prey species (Coleoptera and Orthoptera) found inside or near the nests throughout the breeding season (Table 1). Invertebrates were frozen after collection.

All work was approved by the relevant Portuguese authorities (Instituto da Conservação da Natureza e das Florestas, permit 202/2016/CAPT).

\section{Pellet analysis}

In the laboratory, pellets were disaggregated into small fragments and observed with a binocular magnifying glass. Prey structures (head, pronotum, elytra, mandible, modified tibia, scales, bones) were used to identify prey to the lowest possible taxonomic level, using our own reference collection, based on field and taxonomic guides (Chinery 1988, Zahradnik 1990) and with the help of expert entomologists and a digital database for Portugal (http://naturdata.com/). A conservative criterion was applied, so many prey remains were assigned only to family or genus level. The number of individuals of each taxon was estimated based on the number of unique fragments (e.g. head) or the number of different (only left or only right, or different sized) paired structures (e.g. elytra, mandibles). The diet of adult Rollers was expressed as the frequency of occurrence $(\mathrm{FO}=$ number of pellets in which one prey category occurs in relation to the total number of pellets analysed) and numerical frequency $(\mathrm{NF}=$ number of individuals of one prey category in relation to the total number of consumed prey) of each prey item. To compare the final contribution (in terms of biomass) of Coleoptera and Orthoptera to the diet of Rollers, we estimated for each prey type, the total mass ingested by multiplying its mean weight by the total number of individual items of that species (Supporting Information Table S1). Prey weights were estimated from a sub-sample of all invertebrates collected for SIA that were dried for $48 \mathrm{~h}$ in an oven at $60^{\circ} \mathrm{C}$

This article is protected by copyright. All rights reserved. 
and afterwards weighed with a precision balance (to $0.0001 \mathrm{~g}$ ), as well as from published data (Supporting Information Table S1). For those taxa for which we had no available estimate nor a reference value, we assigned the mean biomass value of all weighed Coleoptera.

\section{Video analysis}

We used the software VLC media player (www.videolan.org) to analyse video recordings and identify prey items delivered to nestlings. In contrast to Orthoptera, Coleoptera could not be identified to the family level and approximately $12 \%$ of all prey could only be identified as "non-Orthoptera". The diet of nestlings is expressed as the numerical frequency of each taxonomic group.

\section{Stable isotope analysis}

Roller RBC samples and soft tissues of invertebrate prey were dried in an oven at $60^{\circ} \mathrm{C}$ for 48 hours and then reduced to a homogenised powder. Prey samples were then processed for lipid extraction by immersion in a 2:1 chloroform/methanol solution with a solvent volume 3-5 times larger than sample volume (Logan et al. 2008). Samples were then mixed for $30 \mathrm{~s}$, left undisturbed for approximately $30 \mathrm{~min}$, further centrifuged for $10 \mathrm{~min}$ at $3400 \mathrm{rpm}$, and the supernatant containing solvent and lipids was removed. This process was repeated at least three times (until the solvent was clear) and samples were then re-dried at $60^{\circ} \mathrm{C}$ for $24 \mathrm{~h}$ to remove any remaining solvent. Between 0.8 and $0.9 \mathrm{mg}$ of each sample was stored in tin cups for stable carbon and nitrogen isotope assays. Isotopic ratios were determined by continuousflow isotope ratio mass spectrometry (unit cost for both $\delta^{13} \mathrm{C}$ and $\delta^{15} \mathrm{~N}=10 €$ ). Results are presented conventionally as $\delta$ values in parts per thousand (\%o) relative to the Vienna Pee Dee Belemnite for $\delta^{13} \mathrm{C}$, and atmospheric nitrogen $\left(\mathrm{N}_{2}\right)$ for $\delta^{15} \mathrm{~N}$. Precision of the isotope ratio analysis, calculated using values from 6 to 9 replicates of laboratory standard material (casein) interspersed among samples in every batch analysis, was 0.11 to $0.15 \%$ and 0.13 to $0.20 \%$ for $\delta^{13} \mathrm{C}$ and $\delta^{15} \mathrm{~N}$, respectively.

\section{Molecular analysis}

Rollers were sexed using the molecular-based method described in Fridolfsson and Ellegren (1999). Briefly, we obtained genomic DNA from blood samples using an extraction kit (E.Z.N.A.® Tissue DNA Kit, Omega Bio-tek Inc., USA), amplified the CHD1W/Z fragments with primers $2550 \mathrm{~F}$ and $2718 \mathrm{R}$, standard PCR conditions and $52^{\circ}$ annealing $\mathrm{T}$, followed by

$3 \%$ agarose electrophoresis to check band sizes. $25 \%$ of the samples were re-amplified to confirm initial results.

This article is protected by copyright. All rights reserved. 


\section{Statistical analyses}

We ran Bayesian mixing models with the SIAR package for $\mathrm{R}$ (Parnell et al. 2008) to estimate the contribution of different potential prey items to adult and nestling diet of Rollers. These models may fail to give a complete picture of diet because not all prey taxa found in pellets were sampled for SIA (Phillips et al. 2014). Thus, SIAR was used to confirm results from other methods (pellets and video analysis) and to determine the relative importance of Coleoptera and Orthoptera (mostly Acrididae, hereafter grasshoppers, and Tettigonidae, hereafter bush crickets) in the diet of adults and nestlings. Within each of these insect orders, prey items with similar isotopic signal were pooled (Table 1) to increase the discriminatory power of the mixing models used (Phillips et al. 2014). Due to the lack of reported discrimination factors for Rollers, we used the mean $( \pm \mathrm{SD})$ value of trophic discrimination factors for blood samples of other bird species reported in published studies reviewed by Caut et al. (2009) (0.59 \pm 1.09 for $\delta^{13} \mathrm{C}$ and $2.37 \pm 0.62$ for $\delta^{15} \mathrm{~N}$, see also Catry et al. 2016a). Trophic discrimination factors are similar for RBC and whole blood (Caut et al. 2009).

To measure and compare the isotopic niche width of Rollers amongst distinct groups (male versus female and adults versus nestlings) we used SIBER package for R (Jackson et al. 2011). We estimated areas of standard ellipses containing c. $40 \%$ of all data $\left(\mathrm{SEA}_{\mathrm{C}}\right)$ because these are less sensitive to extreme values and low sample size than total area. Bayesian standard ellipse areas $\left(\mathrm{SEA}_{\mathrm{B}}\right)$ were used to compare niche width among groups in a quantitative manner (Jackson et al. 2011). We assessed niche (SEA $A_{C}$ ) overlap among groups as follows: for each (i) in one pair (i,j), a value of overlap (Ov[i]) was calculated as the ratio between the area of overlap between the two $\operatorname{SEA}_{C}(\mathrm{~A}[\mathrm{i}, \mathrm{j}])$ and its own $\operatorname{SEA}_{C}(\mathrm{~A}[\mathrm{i}])$, expressed as a proportion $(\mathrm{Ov}[\mathrm{i}]=\mathrm{A}[\mathrm{i}, \mathrm{j}] / \mathrm{Ai}$; Catry et al., 2016b). To further evaluate the existence of sexual diet segregation we used one-way ANOVAs to test for sex differences on carbon and nitrogen isotopic signatures of adults. Moreover, differences in isotopic signatures between mates sampled during courtship or courtship and incubation were also assessed using paired $t$ tests.

All analyses were performed in the $\mathrm{R}$ statistical environment ( $\mathrm{R}$ Development Core Team 2016).

This article is protected by copyright. All rights reserved. 


\section{RESULTS}

\section{Diet composition of adults as revealed by pellet analysis}

In total, 1417 prey items were identified in the 84 pellets analysed, representing at least 43 different taxa (Table 2). Adult Rollers preyed mostly upon insects, with less than $2 \%$ (NF = 1.97) of all prey belonging to other animal taxa. Coleoptera were the dominant prey group, accounting for $82.6 \%$ of all items and occurring in $98.8 \%$ of all pellets. Despite being numerically less dominant, orders such as Orthoptera $(\mathrm{NF}=2.54 \%$; mostly grasshoppers and bush crickets), Hemiptera (NF = 1.27\%; "true bugs") and Hymenoptera (NF = 6.43\%; mostly ants, bees and wasps) were present in more than $20 \%$ of all pellets analysed. Among Coleoptera, beetles belonging to the family Scarabeidae, Chrysomelidae and Carabidae were the most consumed (Table 2). The biomass estimates corroborate the relative importance (FN and FO) of most prey items, except for Orthoptera, which rank higher in biomass due to high per-individual biomass (Table 2). For some of the least frequently consumed taxa it was not possible to obtain biomass values. Overall, when comparing only Coleoptera and Orthoptera (grasshoppers and bush crickets), Coleoptera contributed $90 \%$ of the total biomass consumed by adults.

\section{Diet composition of nestlings as revealed by video-recording}

Analysis of camera images enabled identification of 345 prey items $(20.3 \pm 14.7$ prey items/nest, $n=19$ nests). In contrast to adults, nestling diet was dominated by grasshoppers and bush crickets (Orthoptera), which accounted for $74.2 \%$ of all prey delivered (Table 3 ). Coleoptera represented only $7.5 \%$ of all prey identified, although this value may be underestimated given that $12.2 \%$ of prey delivered were small and could only be identified as "non-Orthoptera" and were likely to include Coleoptera. Non-insect prey items accounted for only approximately $5 \%$ of the diet of nestlings (Table 3 ).

\section{Stable isotope analysis: sex- and age-related diet differences and overall agreement with pellet and video analysis}

There are low levels of morphological sexual dimorphism in adult Rollers. We found marginally significant differences in wing length of Rollers between sexes $\left(F_{1,29}=4.287, P=\right.$ 0.047), with males showing slightly longer wings, but no differences in weight $\left(F_{1,30}=0.275\right.$, $P=0.604)$ or body condition $\left(F_{1,29}=0.119, P=0.732\right)$. SIA showed no differences between male and female Rollers in $\delta^{13} \mathrm{C}$ and $\delta^{15} \mathrm{~N}$ ratios of blood either for the whole sampling period 
$\left(F_{1,33}=0.551, P=0.463\right.$ and $F_{1,33}=0.089, P=0.768$, respectively; $n=15$ males and 20 females) or when subsampling the data and comparing the sexes during the first two weeks after first egg laying, thus reflecting mate feeding period $\left(F_{1,25}=1.285, P=0.268\right.$ and $F_{1,25}=$ 0.038, $P=0.847 ; n=10$ males and 17 females). Similar results were found when comparing mates (paired t-test for all sampled pairs $(n=14): t=1.058, d f=13, P=0.309$ and $t=0.454$, $d f=13, P=0.657$; paired t-test for mate-feeding period $(n=9): t=1.37, d f=8, P=0.207$ and $t=1.473, d f=8, P=0.179$, for $\delta^{13} \mathrm{C}$ and $\delta^{15} \mathrm{~N}$, respectively). Females showed a slightly broader isotopic niche than males (as estimated by both $\mathrm{SEA}_{\mathrm{C}}$ and $\mathrm{SEA}_{\mathrm{B}}$ ), with the isotopic niche of males being totally overlapped by that of females (Table 4 and Supporting Information Fig. S1), suggesting no sex-specific partitioning in resource use.

Carbon $\left(\delta^{13} \mathrm{C}\right)$ and nitrogen $\left(\delta^{15} \mathrm{~N}\right)$ isotopic signatures of Rollers and their prey (corrected by TEF) are presented in Figure 1. The isotopic values of the 11 potential prey species define a broad isotopic space: mean $\delta^{13} \mathrm{C}$ values ranged from -23.87 to $-27.55 \pm 0.17$ and mean $\delta^{15} \mathrm{~N}$ from $2.44 \pm 0.20$ to 8.69 (Table 1). The $\delta^{13} \mathrm{C}-\delta^{15} \mathrm{~N}$ biplot (Fig. 1) shows a clear separation in the isotopic space of the Coleoptera and Orthoptera (grasshoppers and bush crickets) groups due to their non-overlapping $\delta^{15} \mathrm{~N}$ signatures. In addition, it shows that both adult and nestling Rollers lay within the space delineated by main prey categories. SIAR mixing models suggest that, overall, Coleoptera had the highest median contribution (84\%) to the diet of adult rollers during the laying and incubation period, while the consumption of grasshoppers and bush crickets accounted for only $8 \%$ of the whole diet (Fig. 2). Amongst nestlings, results from the isotope mixing model suggest that grasshoppers and bush crickets contribute up to $66 \%$ of the diet, while Coleoptera (all groups pooled) consumption does not exceed $28 \%$ (Fig. 2). Overall, the contrasting relative importance of Coleoptera and Orthoptera (grasshoppers and bush crickets) to the diet of adult and nestling Rollers as depicted by SIAR mixing models is consistent with the results revealed by the other diet assessment techniques (pellets and video recording, Fig. 3). The isotopic niche width of nestlings was narrower and did not overlap with that of laying/incubating adults (Table 4 and Supporting Information Fig. S1).

\section{DISCUSSION}

Previous studies of the diet of Rollers on their European breeding grounds used conventional techniques (e.g. Cassola \& Lovari 1979, Avilés \& Parejo 1997, 2002, Tidmarsh 2004) and, to our knowledge, no study has tested for differences in diet between the sexes or between 
adults and nestlings in the same year. Here, we combine three different methods (pellet and video recording analyses and SIA) to describe the diet of adult (both females and males) and nestling Rollers. Results highlight the role of SIA in the study of avian trophic ecology, overcoming previous methodological bias and allowing the identification of intra-population variation in diet.

\section{Diet of adults and nestlings}

We identified 43 different taxa (of 13 different orders) consumed by adult Rollers in our study area, supporting the description of an extremely polyphagous species (Del Hoyo et al. 2001). Our results suggest that adults feed mainly on hard-bodied insects, with beetles (Coleoptera) representing approximately $84 \%$ of all items consumed. Dung (Scarabeidae), leaf (Chrysomelidae) and ground (Carabidae) beetles made the greatest contribution to the diet of adult Rollers, likely reflecting the traditional extensive practices of cereal cultivation, with large areas of low-intensity grazed fallows. All are known to play an important role in agriculture by improving nutrient recycling and soil structure and by protecting livestock and cultures from pests (Kromp 1999, Parsons \& Cuthbertson 2001, Brown et al. 2010). Our results do not corroborate the findings of Avilés and Parejo (2002) who reported an Orthoptera-based diet in south-west Spain during the pre-laying and laying periods. These authors explained the lower consumption of Coleoptera in their study (when compared for instance with central and northern European breeding areas) as being a consequence of the higher abundance of more profitable Orthoptera. Grasshoppers and bush-crickets are indeed large, highly energy-rich prey, also very abundant in our study area and highly consumed by other species (Catry et al. 2016a, Catry et al. 2017b). However, in our study area, they are not abundant at the beginning of the breeding season, slowly increasing throughout mid-May and peaking in availability in mid-June (Catry et al. 2017b). Pellet collection was biased towards the mate-feeding and incubation periods (only $20 \%$ of all pellets were collected in June) as well as adult blood sampling for SIAR (see Methods) and thus both methods might be slightly underestimating the importance of these prey in the diet of adult Rollers over the whole breeding season. Indeed, Catry et al. (2016a) showed that, in the same area, Lesser Kestrels Falco naumanni significantly increased their consumption of grasshoppers throughout the breeding season.

Diet segregation between sexes has often been reported among bird populations (Forero et al. 2002, Phillips et al. 2004, Catry et al. 2016a). Several, non-exclusive factors can lead to this, including avoidance of intraspecific competition, niche specialization due to

This article is protected by copyright. All rights reserved. 
sexual size dimorphism or the different roles, and hence energetic needs, of males and females during reproduction (Catry et al. 2005). Our results suggest no sex-specific diet segregation in Rollers, as we found no differences in $\delta^{13} \mathrm{C}$ and $\delta^{15} \mathrm{~N}$ ratios of blood between males and females during the mate feeding and incubation periods, with females showing only a slightly wider isotopic niche than males. Rollers show few sex-specific morphological and plumage traits (field-identification of sex is difficult; this study) making niche specialization driven by sexual size dimorphism unlikely. After egg laying, both sexes incubate the eggs, brood and feed the young, even though females are thought to take a larger share of incubation duties (Cramp \& Simmons 1988). In contrast to a sympatric species, the Lesser Kestrel, where females are preferentially fed with higher energetic prey (mole crickets) during the courtship period, resulting in sexual diet segregation (Catry et al. 2016a), male Rollers do not seem to feed their mates with different prey than those consumed by themselves. Lower availability of high quality prey (Rollers lay, on average, two weeks later than Lesser Kestrels when mole crickets decline significantly, and grasshoppers and bush crickets are scarce; Catry et al. 2012, Catry et al. 2017b) during the pre-laying period of Rollers could partially explain the absence of diet segregation.

Unlike adults, nestling diet was dominated by Orthoptera, mainly grasshoppers, agreeing with results of previous diet studies (Avilés \& Parejo 2002, Tidmarsh 2004) and with recent work developed in the same area (Catry et al. 2017a), which revealed a high preference of foraging Rollers during the chick rearing period for fallow land, where grasshopper abundance was highest. Parent-offspring segregation in diet composition often results from the different (higher) nutritional needs of rapidly growing chicks (Alonso et al. 2012, Raya Rey et al. 2012, Beaulieu \& Sockman 2014). Although the diet preferences of adults and nestlings could be compared using SIA methods, this would require the two age classes to be sampled at the same time. In this study, due to the difficulty of catching adult Rollers during the chick-rearing period, sampling of age groups only marginally overlapped in time, thus jeopardizing the accurate assessment of any difference in the trophic ecology of adults and nestlings. Nevertheless, blood ratios of carbon stable isotopes suggest a slight seasonal diet shift in adult Rollers in the opposite direction from the signature of nestlings, thus suggesting some degree of diet segregation between parents and offspring (Fig. 4). Under this scenario, we believe that, as suggested for Lesser Kestrels (Catry et al. 2016a), adult Rollers may feed their offspring a higher proportion of soft-bodied grasshoppers and bush crickets compared to prey consumed by themselves given the relatively large size, higher digestibility and high energetic value of these prey when compared to hard-bodied, 
smaller and thus less profitable prey, such as Coleoptera. Moreover, during chick-rearing, Rollers are central place foragers and single-prey loaders and should thus maximize the rate of energy delivered per provisioning trip (Stephens \& Krebs 1986).

\section{Strengths and drawbacks of different diet-assessment techniques}

Amongst all methods used, pellet analysis provided the highest number of identifiable prey taxa, with more than 1400 prey items and 43 different taxa identified. Whilst being widely used in the study of avian trophic ecology as an inexpensive, non-invasive and thorough technique, pellet analysis is very time-consuming (approximately two months to analyse 84 pellets), often represents a snapshot of a consumer's diet and can lead to biased results due to variability in the digestibility of food items (Sutherland 2004). Alternatively, isotopic ratios in bird tissue reflect its diet at the time of tissue synthesis in a predictable manner, but prior knowledge of the diet of the target species and isotopic signatures of prey is required, as well as of the shift in isotope ratio between diet and consumer tissue ( Hobson \& Clark 1992). Moreover, SIAR mixing models work best when food sources are well separated (Gannes et al. 1997, Phillips \& Gregg 2001) and because the discriminatory power of mixing models is negatively affected by a high number of food sources included (Phillips et al. 2014), diet assessment of highly polyphagous species, such as the Roller, can be compromised. Nonetheless, this technique enables sampling high numbers of individuals and prey items. Blood isotopic signatures of adult Rollers revealed a Coleoptera-dominated diet showing an overall agreement with the results obtained through pellet analysis. However, the detailed contribution of different species or families among Coleoptera could not be accurately assessed, either because some taxa showed similar isotopic signatures or because some others could not be sampled and included in the modelling. On the other hand, we highlight the potential of SIA for investigating intra-specific sexual variation in dietary regimes which is often unfeasible through conventional approaches of diet assessment (see also Catry et al. 2016a).

Results from video records and SIA to assess the diet of nestling Rollers also show a high agreement between techniques. When compared to other conventional diet assessment techniques such as neck collars (which prevent chicks from swallowing the food delivered by their parents) or analysis of nest remains, the use of cameras is generally less invasive, can allow a larger sample of nests to be monitored for longer periods, and creates a visual archive that can be reviewed later for different research objectives. Nevertheless, this method yielded the largest proportion of unidentified prey (especially small items) which represents one of its

This article is protected by copyright. All rights reserved. 
major limitations (García-Salgado et al. 2015). Indeed, the difference in the relative contribution of Coleoptera to nestling diet obtained through video recording (7.5\%) and SIA $(28.0 \%)$ is likely to be explained by the relatively high proportion of undetermined nonOrthoptera (likely to include beetles) in the video analysis, suggesting that SIAR mixing models could perform better in the assessment of nestling diet. Advances in technology and the growing availability of affordable high-resolution cameras will enable the identification of a higher proportion of prey items but will be unlikely to reduce the time needed to retrieve all the information from the camera images. Finally, the use of stable isotopes is also likely to enable the accurate assessment of age-related segregation in the diet with the advantage of using a single method, constrained to the same bias.

\section{Conclusions}

Our results highlight the use of SIA as a useful diet assessment tool to unveil the trophic ecology of birds. This technique is especially relevant in allowing information on individuallevel diet that is impossible to obtain through more traditional methods with higher taxonomic resolution (e.g. pellet analysis). Due to each method-specific set of limitations and biases, the choice of the sampling techniques used in diet studies must vary according to the purpose of each study. Overall, and agreeing with recent studies (Casper et al. 2007, Oehm et al. 2016, 2017), we recommend using a combined analytical approach to maximize insights into the study of bird diet.

The traditional cereal-steppe landscape of the Castro Verde SPA, encompassing large areas of fallows with low intensity grazing, seems to offer a high-quality foraging habitat for Rollers (Catry et al. 2017a). High breeding success recorded in our population (four-year average productivity $=3.7 \pm 0.3, \mathrm{n}=153$ ), when compared with other European populations (e.g. Samwald \& Samwald 1989, Sosnowski \& Chmielewski 1996, Avilés et al. 1999), and population increase contrasting with overall decline across the country (Catry et al. 2011) support this hypothesis. These results suggest that Rollers are feeding themselves and their offspring with high quality prey and that the implementation of effective management measures to maintain the current foraging habitats are crucial to the conservation of Rollers and other target farmland species. In the study area, grasshoppers and bush crickets are at highest densities in fallows (Catry et al. 2017), which were shown to be critical for chick provisioning and thus for ensuring high breeding success. Therefore, the maintenance of traditional extensive practices of cereal cultivation with large areas of low-intensity grazed fallows is strongly recommended (see also Catry et al. 2017)

This article is protected by copyright. All rights reserved. 
We are indebted to Prof. Artur Serrano and Carlos Aguiar for their help in identifying invertebrate remains from Roller pellets. Thanks are due to João Gameiro for helping during fieldwork and to the municipality of Castro Verde for providing accommodation. Two anonymous referees made useful comments on a previous version of the manuscript. Thanks are due for the financial support to InBIO (UID/BIA/50027/2013 and POCI-01-0145-FEDER-006821) and CESAM (UID/AMB/50017 - POCI01-0145-FEDER-007638), to FCT/MCTES through national funds (PIDDAC), and the co-funding by the FEDER, within the PT2020 Partnership Agreement and Compete 2020. IC and MCS were supported by post-doctoral grants from FCT (SFRH/BPD/102637/2014 and SFRH/BPD/85700/2012, respectively) and TC by IF/00694/2015.

\section{REFERENCES}

Alonso, H., Granadeiro, J.P., Paiva, V.H., Dias, A.S., Ramos, J.A. \& Catry, P. 2012. Parent-offspring dietary segregation of Cory's shearwaters breeding in contrasting environments. Mar. Biol. 159: 1197-1207.

Avilés, J.M., Parejo, D. 1997. Diet of roller (Coracias garrulus) nestlings in a Mediterranean area (Extremadura, SW Spain). Ardeola 44: 235-237.

Avilés, J.M., Sánchez, J. M., Sánchez, A., Parejo, D. 1999. Breeding biology of Roller Coracias garrulus L. 1758 in farming areas of the southwest of the Iberian Peninsula. Bird Study 46: 217-223.

Avilés, J.M., \& Parejo, D. 2002. Diet and prey type selection by Rollers Coracias garrulus during the breeding season in southwest of the Iberian Peninsula. Alauda 66: 313-314.

Barrett, R.T., Camphuysen, C.J., Anker-Nilssen, T., Chardine, J.W., Furness, R.W., Garthe, S., Hüppop, O., Leopold, M.F., Montevecchi, W.A., \& Veit, R.R. 2007. Diet studies of seabirds: a review and recommendations. ICES J. Mar. Sci. 64: 1675-1691.

Bearhop, S., Adams, C.E., Waldron, S., Fuller R.A., \& Macleod, H. 2004. Determining trophic niche width: A novel approach using stable isotope analysis. J. Anim. Ecol. 73: 10071012.

This article is protected by copyright. All rights reserved. 
Beaulieu, M., \& Sockman, K.W. 2014. Comparison of optimal foraging versus life-history decisions during nestling care in Lincoln's Sparrows Melospiza lincolnii through stable isotope analysis. Ibis 156: 424-432.

BirdLife International 2004. Birds in the European Union: a status assessment. Wageningen, the Netherlands: BirdLife International.

Bond, A.L., \& Diamond, A.W. 2011. Recent Bayesian stable isotope mixing models are highly sensitive to variation in discrimination factors. Ecol. Appl. 21: 1017-1023.

Brown, J., Scholtz, C. H., Janeau, J. L., Grellier, S., \& Podwojewski, P. 2010. Dung beetles (Coleoptera: Scarabaeidae) can improve soil hydrological properties. Applied Soil Ecol. 46: 9.

Casper, R.M., Jarman, S.N., Gales, N.J., \& Hindell, M.A. 2007. Combining DNA and morphological analyses of faecal samples improves insight into trophic interactions: A case study using a generalist predator. Mar. Biol. 152: 815-825.

Cassola, F., \& Lovari, S. 1979. Food habits of Rollers during the nesting season, Bolletino di zoologia 46: 87-89.

Catry, P., Phillips, R.A., \& Croxall, J.P. 2005. Sexual segregation in birds: patterns, processes and implications for conservation. In Ruckstuhl, K.E. \& Neuhaus, P. (eds) Sexual segregation in vertebrates: ecology of the two sexes. 351-378. Cambridge, UK: Cambridge University Press.

Catry, I., Silva, J.P., Pereira, A., Cavaco, A., Cardoso, A., Martins, A., Delgado, A., Sanches, A.R., Santos, A., Estanque, B., Franco, C., Cruz, C.M., Pacheco, C., Conde, C., Leitão, D., Pereira, E., Matilde, E., Abegão, F., Moital, F., Romba, F. 2011. Distribution and population trends of the European roller in pseudo-steppe areas of Portugal: results from a census in sixteen SPAs and IBAs. Airo 21: 3-14.

Catry, I., Franco, A.M.A., \& Sutherland, W.J. 2012. Landscape and weather determinants of prey availability: implications for the lesser kestrel Falco naumanni. Ibis 154: 111-123. 
Catry, I., Catry, T., Alho, M., Franco, A.M.A., Moreira, F. 2016a. Sexual and parentoffspring dietary segregation in a colonial raptor as revealed by stable isotopes. J. Zool. 299: 58-67.

Catry, T., Lourenço, P.M., Lopes, R.J., Carneiro, C., Alves, J.A., Costa, J., RguibiIdrissi, H., Bearhop, S., Piersma, T., \& Granadeiro, J.P. 2016b. Structure and functioning of intertidal food webs along an avian flyway: a comparative approach using stable isotopes. Funct. Ecol 30: 468-478.

Catry, I., Marcelino, J., Franco, A.M.A., \& Moreira, F. 2017a. Landscape determinants of European roller foraging habitat: implications for the definition of agri-environmental measures for species conservation. Biod. and Conserv. 26: 553-566.

Catry, T., Moreira, F., Alcazar, R., Rocha, P., \& Catry, I. 2017b. Mechanisms and fitness consequences of laying decisions in a migratory raptor. Behav. Ecol. 28: 222-232.

Caut, S., Angulo, E., \& Courchamp, F. 2009. Variation in discrimination factors $(\Delta 15 \mathrm{~N}$ and $\Delta 13 \mathrm{C}$ ): the effect of diet isotopic values and applications for diet reconstruction. $J$. Applied Ecol. 46: 443-453.

Chynery, M. 1988. Insectos de España y Europa. Barcelona, Spain: Ediciones Omega.

Cramp, S. \& Simmons, K.E.L. 1988. The birds of the Western Paleartic, Vol.V. Oxford: Oxford University Press.

Del Hoyo, J., Elliott, A., \& Sargatal, J. 2001. Handbook of the birds of the world, Vol 6. Mousebirds to Hornbills. Barcelona: Lynx Edn.

Dicken, M.L., Hussey, N.E., Christiansen, H.M., Smale, M.J., Nkabi, N., Cliff, G., \& Wintner S.P. 2017. Diet and trophic ecology of the tiger shark (Galeocerdo cuvier) from South African waters. PLoS ONE 12(6): e0177897. 
Donald, P.F., Muirhead, L.B., Buckingham, D.L., Evans, A.D., Kirby, W.B., \& Gruar, D.J. 2001. Body condition, growth rates and diet of Skylark Alauda arvensis nestlings on lowland farmland. Ibis 143: 658-669.

Forero, M.G., Hobson, K.A., Bortolotti, G.R., Donázar, J.A., Bertellotti, M., \& Blanco, G. 2002. Food resource utilisation evaluated through stable-isotope analysis: segregation by sex and age and influence on offspring quality. Mar. Ecol. Prog. Ser. 234: 289-299.

Fridolfsson, A.K., \& Ellegren, H. 1999. A simple and universal method for molecular sexing of non-ratite birds. J. Avian Biol. 30: 116-121.

Gameiro, J. 2015. Evolução do habitat de aves estepárias no Sudoeste da Península Ibérica no contexto de um ambiente em mudança. Master thesis dissertation. Faculty of Science, University of Lisbon, Portugal.

Gannes, L.Z., O’Brien, D.M., \& Martínez del Rio, C. 1997. Stable isotopes in animal ecology: assumptions, caveats and a call for more laboratory experiments. Ecol. 78: 12711276.

García-Salgado, G., Rebollo S., Pérez-Camacho, L., Martínez-Hesterkamp, S., Navarro, A., \& Fernández-Pereira, J.M. 2015. Evaluation of trail-cameras for analyzing the diet of nesting raptors using the Northern Goshawk as a model. PLOS ONE 10(5): e0127585.

Grémillet, D., Enstipp, M. R., Boudiffa, M., \& Liu, H. 2006. Do cormorants injure fish without eating them? An underwater video study. Mar. Biol. 148: 1081-1087.

Hobson, K.A. \& Clark, R.G. 1992. Assessing avian diets using stable isotopes 2. Factors influencing diet-tissue fractionation. Condor 94: 189-197.

Hobson, K.A., \& Wassenaar, L.I. 2008. Tracking animal migration with stable isotopes. Vol. 2. San Diego, California: Academic Press, Terrestrial Ecology Series, Elsevier Inc.

Hounsome, T., O'Mahony, D., Delahay, R. 2004. The diet of Little Owls Athene noctua in Gloucestershire, England. Bird Study 51: 282-284.

This article is protected by copyright. All rights reserved. 
Inger, R., Ruxton, G.D., Newton, J., Colhoun, K., Robinson, J.A., Jackson, A.L., \& Bearhop, S. 2006. Temporal and intrapopulation variation in prey choice of wintering geese determined by stable isotope analysis. J. Anim. Ecol. 75: 1190-1200.

Jackson, A.L., Inger, R., Parnell, A.C., \& Bearhop, S. 2011. Comparing isotopic niche widths among and within communities: SIBER - Stable Isotope Bayesian Ellipses in R. $J$. Anim. Ecol. 80: 595-602.

Kovacs, A., Barov, B., Orhun, C., Gallo-Orsi, U. 2008. International species action plan for the European roller Coracias garrulus garrulus. http://ec.europa.eu/environment/nature/conservation/wildbirds/action_plans/docs/coracias_ga rrulus_garrulus.pdf/ Accessed 29 September 2017.

Kromp, B. 1999. Carabid beetles in sustainable agriculture: a review on pest control efficacy, cultivation aspects and enhancement. Agric., Ecos. and Env. 74: 187-228.

Longmire, J.L., Maltbie, M., \& Baker, R.J. 1997. Use of" lysis buffer" in DNA isolation and its implication for museum collections. Museum of Texas Tech University.

Logan, J.M., Jardine, T.D., Miller, T.J., Bunn, S.E., Cunjak, R.A., \& Lutcavage, M.E. 2008. Lipid corrections in carbon and nitrogen stable isotope analyses: comparison of chemical extraction and modelling methods. J. Anim. Ecol. 77: 838-846.

Marti, C.D., Bechard, M., \& Jaksic, F.M. 2007. Food habits. In Bird, D.M. \& Bildstein, K.L. (eds) Research and Management Techniques. 129-149. Blaine, WA: Hancock House Publishers.

Morrison, M., Ralph, C., Verner, J., \& Jehl, J. 1990. Avian foraging: Theory, methodology, and applications. Los Angeles: Cooper Ornithological Society.

Nazaro, M.G., \& Blendinger, P.G. 2017. How important are arthropods in the diet of fruiteating birds? Wil. J. Ornit. 129: 520-527. 
Oehm, J., Thalinger, B., Mayr, H., \& Traugott, M. 2016. Maximizing dietary information retrievable from carcasses of Great Cormorants Phalacrocorax carbo using a combined morphological and molecular analytical approach. Ibis 158: 51-60.

Oehm, J., Thalinger, B., Eisenkölbl, S., \& Traugott, M. 2017. Diet analysis in piscivorous birds: What can the addition of molecular tools offer? Ecol.and Evol. 7: 1984-1995.

Orłowski, G., \& Karg, J. 2011. Diet of nestling Barn Swallows Hirundo rustica in rural areas of Poland. Cent. Eur. J. Biol. 6: 1023-1035.

Parnell, A., Inger, R., Bearhop, S., \& Jackson, A.L. 2008. SIAR: Stable isotope analysis in R. Available at: http://cran.r- project.org/web/packages/siar

Parsons, W.T., \& Cuthbertson, E.G. 2001. Noxious Weeds of Australia. 2nd ed. Collingwood: CSIRO Publishing.

Phillips, D.L., \& Gregg, J.W. 2001. Uncertainty in source partitioning using stable isotopes. Oecol. 127: 171-179.

Phillips, R.A., Silk, J.R.D., Phalan, B., Catry, P., \& Croxall, J.P. 2004. Seasonal sexual segregation in two Thalassarche albatross species: competitive exclusion, reproductive role specialization or foraging niche divergence? Proc. R. Soc. Lond. B 271: 1283-1291.

Phillips, D.L., Inger, R., Bearhop, S., Jackson, A.L., Moore, J.W., Parnell, A.C., Semmens, B.X., Ward, E.J. 2014. Best practices for use of stable isotope mixing models in food-web studies. Can. J. Zool. 92: 823-835.

R Development Core Team 2016. R: A language and environment for statistical computing. Vienna, Austria: R Foundation for Statistical Computing. Available at: http:// www.Rproject.org/.

Raya Rey, A., Polito, M., Archuby, D. \& Coria, N. 2012. Stable isotopes identify age- and sex- specific dietary partitioning and foraging habitat segregation in southern giant petrels breeding in Antarctica and southern Patagonia. Mar. Biol. 159: 1317-1326. 
Redpath, S.M., Clarke, R., Madders, M., \& Thirgood, S.J. 2001. Assessing raptor diet: comparing pellets, prey remains, and observational data at hen harrier nests. Condor 103: 184-188.

Resano-Mayor, J., Hernández-Matías, A., Real, J., Parés, F., Inger, R., \& Bearhop, S. 2014. Comparing pellet and stable isotope analyses of nestling Bonelli's Eagle Aquila fasciata diet. Ibis 156: 176-188.

Rodríguez, C., Tapia, L., Kieny, F. \& Bustamante, J. 2010. Temporal changes in lesser kestrel Falco naumanni diet during the breeding season in southern Spain. J. Raptor Res. 44: 120-128.

Samwald, O. \& Samwald, F. 1991. Population numbers, phenology, breeding biology and decline of the roller in Styria, Austria, Egretta 32: 37-57.

Samwald, O. \& Štumberger, B. 1997. Roller (Coracias garrulus). In Hagemeijer, W.J.M. \& Blair, M.J. (eds) The EBCC atlas of European breeding birds: Their distribution and abundance. 436-437. London, UK: T \& AD Poyser.

Sosnowski, J. \& Chmielewski, S. 1996. Breeding biology of the Roller Coracias garrulus in Puszcza Forest (Central Poland). Acta Ornithol. 31: 119-131.

Stephens, D.W., \& Krebs, J.R. 1986. Foraging Theory. Princeton, New Jersey: Princeton University Press.

Sutherland, W.J. 2004. Diet and foraging behavior In Sutherland, W.J., Newton, I. \& Green, R. (eds) Bird ecology and conservation: A handbook of techniques. 233-250. Oxford, UK: Oxford University Press.

Tidmarsh, R. 2004. Nest box contents as an indicator of nestling diet in the European Roller Coracius garrulus population of the vallee des Baux in 2003. In Tron, F. (ed) Travaux de recherche et de conservation de la nature dans la vallée des Baux en 2003. France: A Rocha France.

This article is protected by copyright. All rights reserved. 
Tucker, G.M., \& Heath, M.F. 1994. Birds in Europe: their conservation status. Cambridge: BirdLife International.

Votier S.C., Crane J.E., Bearhop S., de Leon A., McSorley C., Minguez E., Mitchell I., Parsons, M., Phillips, R.A., \& Furness, R.W. 2007. Nocturnal foraging by great skuas Stercorarius skua: implications for conservation of storm-petrel populations. J. Ornit. 147: 405-413.

Wheelwright, N.T. 1986. The diet of American robins: an analysis of U.S. biological survey records. Auk 103: 710-725.

Zahradnik, J. 1990. Guía de los Coleópteros de España y de Europa., Barcelona, Spain: Ediciones Omega.

\section{FIGURES}

\section{Figure Captions}

Figure 1. Carbon $(\delta 13 \mathrm{C})$ and nitrogen $(\delta 15 \mathrm{~N})$ stable isotopes of adult (male and female) and nestling Rollers (red blood cells) and their potential prey (mean $\pm \mathrm{SD}$, corrected for trophic enrichment factor; see methods). Prey taxa, as considered for isotope mixing models (SIAR): 1- Coleoptera 1 (Bubas bison), 2 - Coleoptera 2 (Chrysolina bankii), 3 - Coleoptera 3 (Amphimallon nigrum and Pterostichus globosus), 4 - Coleoptera 4 (Silpha sp. and Protaetia sp.), 5 - Coleoptera 5 (Carabus rugosus and Sepidium sp.), 6 - Grasshoppers (Acrididae) and bush crickets (Tettigonidae), 7-Gryllotalpa sp.

Figure 2. Relative contribution of prey in the diet of adult and chick Rollers as estimated by SIAR mixing models. Black dots represent the mode and boxes present the 50, 75 and 95\% credible intervals. For details on composition of Coleoptera groups see Table 1. 
Figure 3. Overall agreement between estimated contributions of the two main prey groups for the diet of adults (dark) and nestling (grey) Rollers revealed by pellet analysis and camera images (numerical frequency represented as columns), respectively, and SIAR (dots).

Figure 4. Blood (a) $\delta^{13} \mathrm{C}$ and (b) $\delta^{15} \mathrm{~N}$ stable isotope signatures of adult (black dots) and nestling (grey dots) Rollers along the breeding season in 2016, Castro Verde, Portugal. Sampling date follows the Julian date calendar (10 April =100). Mean grasshopper and bush cricket isotopic signatures are presented as a dashed line for comparison purposes (corrected for trophic enrichment factor).

\section{Figure 1}

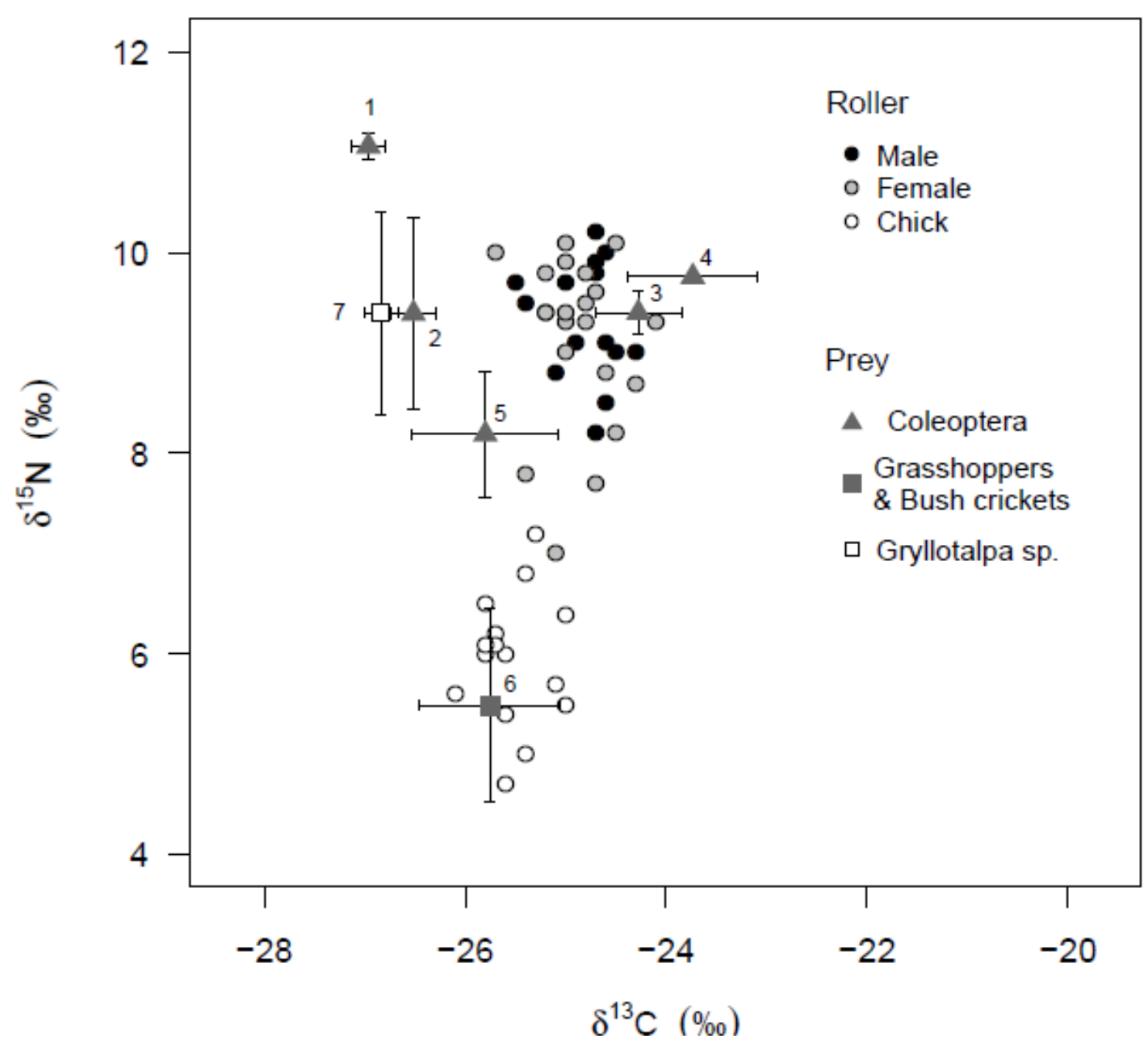

This article is protected by copyright. All rights reserved. 
Figure 2

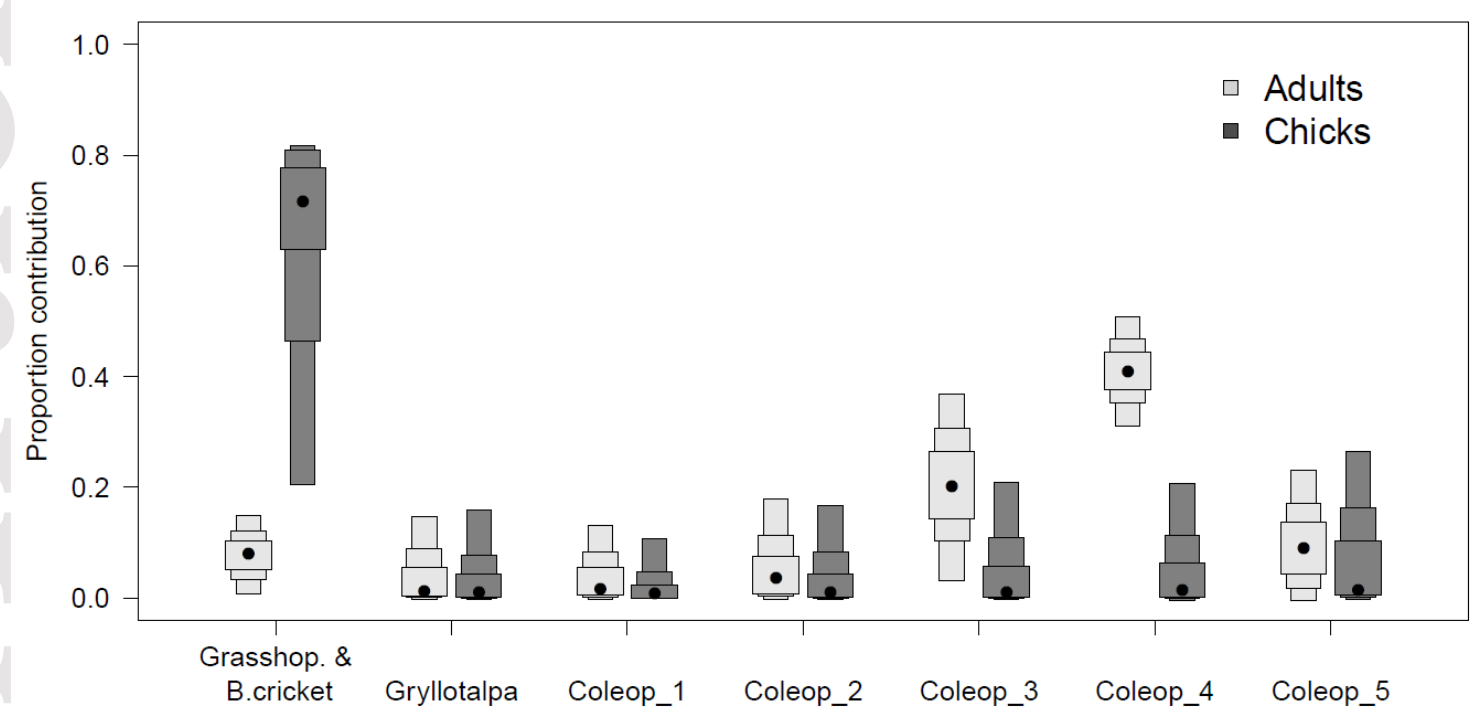

This article is protected by copyright. All rights reserved. 
Figure 3

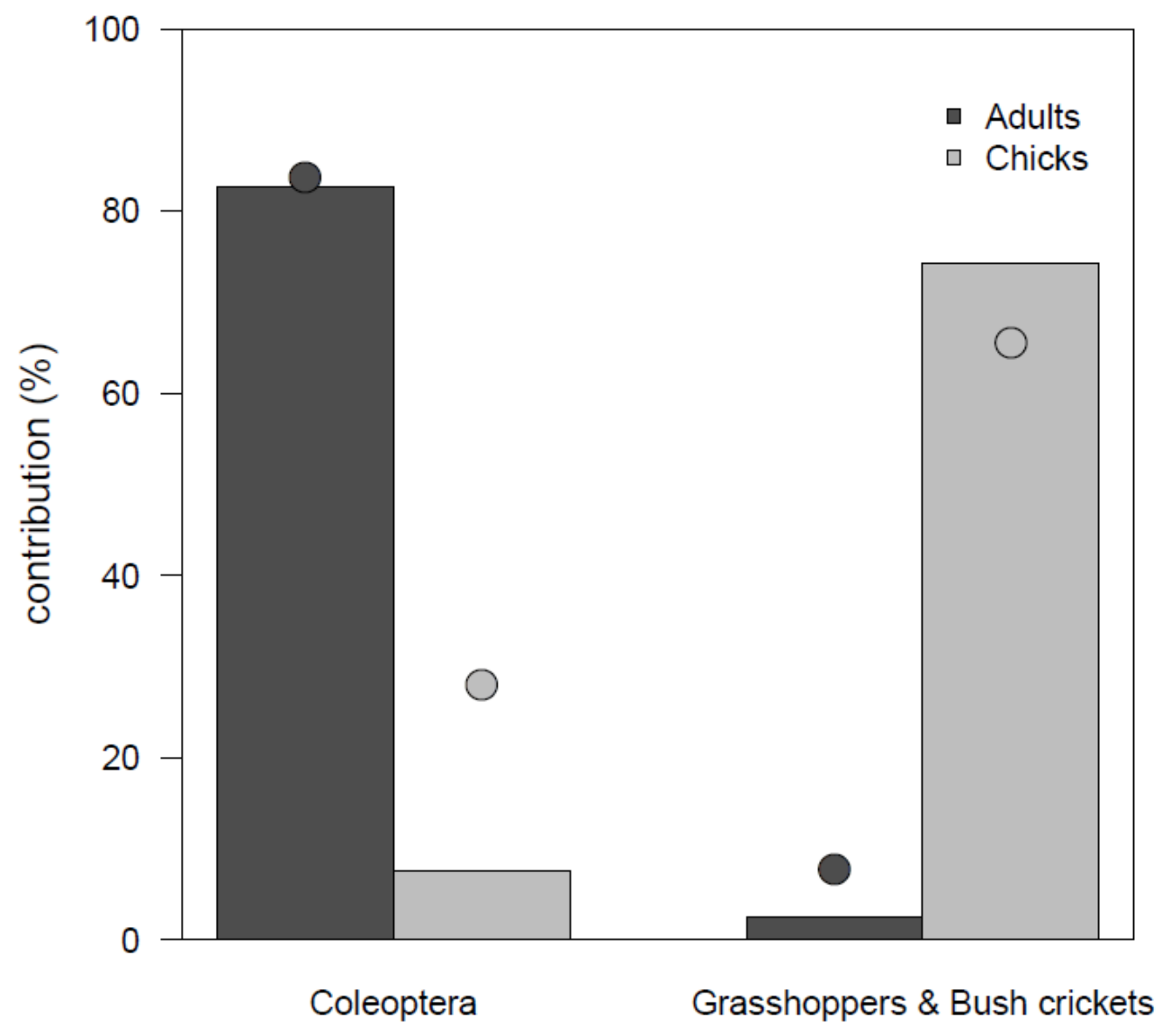

This article is protected by copyright. All rights reserved. 
Figure 4
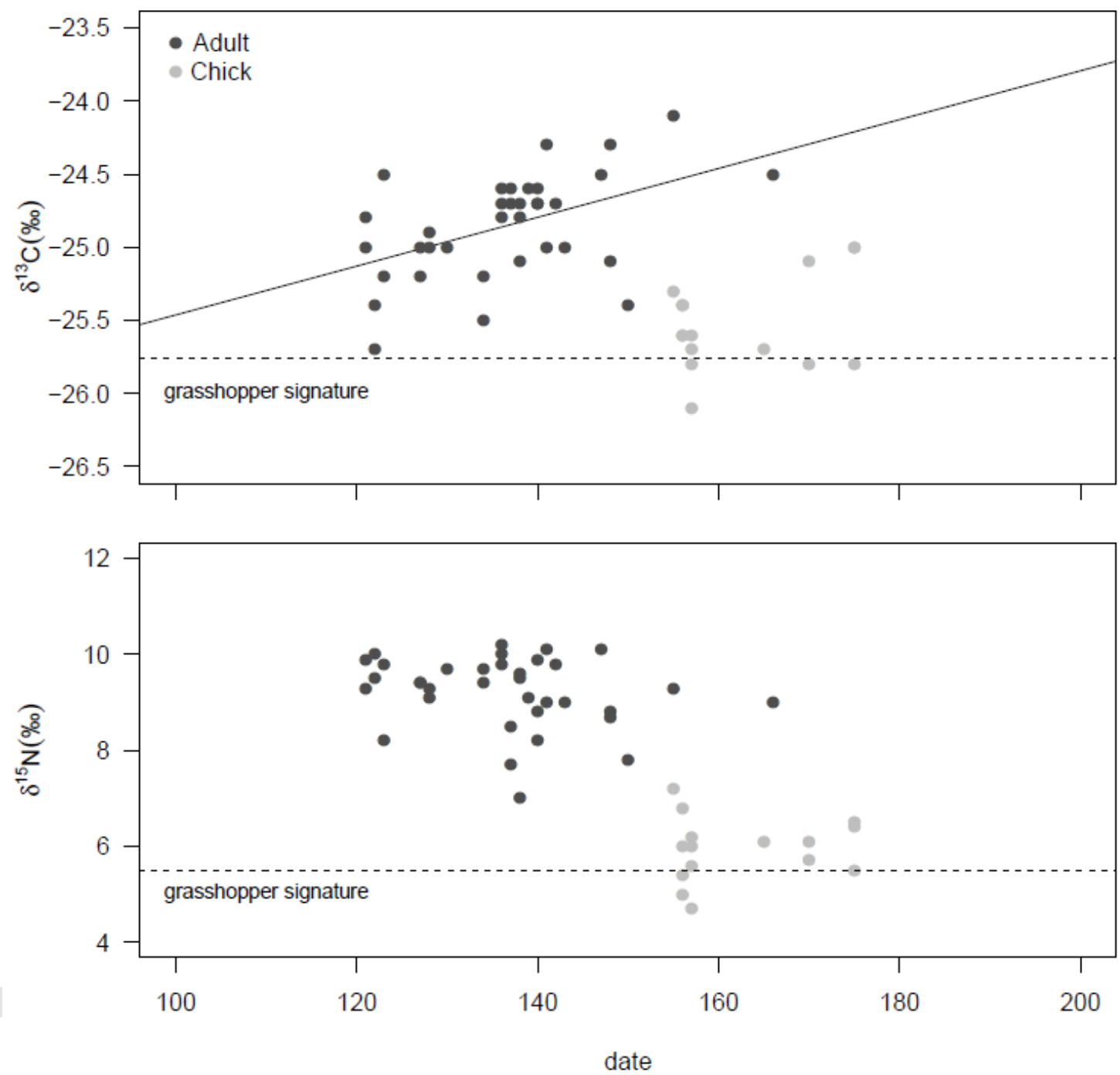

This article is protected by copyright. All rights reserved. 


\section{TABLES}

Table 1. Mean ( \pm SD) carbon $\left(\delta^{13} \mathrm{C}\right)$ and nitrogen $\left(\delta^{15} \mathrm{~N}\right)$ isotopic values of blood (red blood cells) of male, female and nestling Rollers and several of their key prey taxa, collected in Castro Verde, southern Portugal. Sample size is given for all taxa/groups and, whenever applicable, the total number of individuals pooled in prey samples is given in parenthesis. SIAR group defines a priori combination of potential food sources with similar isotopic signal used in mixing models (see methods).

\begin{tabular}{|c|c|c|c|c|}
\hline & $\delta^{13} \mathrm{C}$ & $\delta^{15} \mathrm{~N}$ & $\mathrm{n}$ & $\begin{array}{l}\text { SIAR } \\
\text { group }\end{array}$ \\
\hline \multicolumn{5}{|l|}{ ROLLER } \\
\hline \multicolumn{5}{|l|}{ Adults } \\
\hline Males & $-24.83 \pm 0.34$ & $9.33 \pm 0.58$ & 15 & \\
\hline Females & $-24.87 \pm 0.37$ & $9.14 \pm 0.87$ & 20 & \\
\hline All & $-24.85 \pm 0.36$ & $9.22 \pm 0.75$ & 35 & \\
\hline Nestlings & $-25.53 \pm 0.32$ & $5.95 \pm 0.66$ & 15 & \\
\hline \multicolumn{5}{|l|}{ PREY } \\
\hline \multicolumn{5}{|l|}{ Coleoptera } \\
\hline Bubas bison & $-27.55 \pm 0.17$ & $8.69 \pm 0.12$ & $2(4)$ & 1 \\
\hline Chrysolina bankii & $-27.11 \pm 0.23$ & $7.02 \pm 0.95$ & $3(13)$ & 2 \\
\hline Amphimallon nigrum & $-25.79 \pm 0.72$ & $7.11 \pm 0.24$ & $2(21)$ & 3 \\
\hline Carabus rugosus. & $-26.70 \pm 0.79$ & $5.85 \pm 1.04$ & 2 & 5 \\
\hline Sepidium sp. & $-26.08 \pm 0.72$ & $5.78 \pm 0.34$ & 3 & 5 \\
\hline Silpha sp. & -24.78 & 7.41 & $1(4)$ & 4 \\
\hline Protaetia sp. & -23.87 & 7.37 & $1(2)$ & 4 \\
\hline Pterostichus ebenus & $-25.95 \pm 0.06$ & $6.95 \pm 0.23$ & $2(14)$ & 3 \\
\hline \multicolumn{5}{|l|}{ Orthoptera } \\
\hline Tettigonidae & $-25.83 \pm 0.61$ & $2.44 \pm 0.20$ & $3(4)$ & 6 \\
\hline Acrididae & $-26.86 \pm 0.28$ & $3.79 \pm 0.96$ & $3(17)$ & 6 \\
\hline Gryllotalpa sp. & $-27.43 \pm 0.17$ & $7.03 \pm 1.01$ & $3(6)$ & 7 \\
\hline
\end{tabular}

This article is protected by copyright. All rights reserved. 
Table 2. Diet composition of adult breeding European Rollers in Castro Verde, southern Portugal, based on pellet analysis $(n=84)$. Frequency of occurrence (FO), numerical frequency (NF) and dry biomass (g) are given for each taxa. NI = non-identified.

\begin{tabular}{|c|c|c|c|}
\hline PHYLUM/CLASS/Order/Family/Sub-family & FO (\%) & NF (\%) & Biomass (g) \\
\hline \multicolumn{4}{|l|}{ MOLLUSCA } \\
\hline \multicolumn{4}{|l|}{ GASTROPODA } \\
\hline Gastropoda undet. & $3.57(3)$ & $0.42(6)$ & --- \\
\hline \multicolumn{4}{|l|}{ ARTHROPODA } \\
\hline \multicolumn{4}{|l|}{ DIPLOPODA } \\
\hline \multicolumn{4}{|l|}{ Julidae } \\
\hline Julidae NI & $5.95(5)$ & $0.35(5)$ & --- \\
\hline \multicolumn{4}{|l|}{ ARACHNIDA } \\
\hline \multicolumn{4}{|l|}{ Solifugae } \\
\hline \multicolumn{4}{|l|}{ Daesiidae } \\
\hline Gluvia dorsalis & $5.95(5)$ & $0.49(7)$ & $1.03^{1}$ \\
\hline \multicolumn{4}{|l|}{ Scorpiones } \\
\hline \multicolumn{4}{|l|}{ Buthidae } \\
\hline Buthus occitanus & $1.19(1)$ & $0.07(1)$ & --- \\
\hline \multicolumn{4}{|l|}{ INSECTA } \\
\hline \multicolumn{4}{|l|}{ Dermaptera } \\
\hline Dermaptera NI & $9.52(8)$ & $5.01(71)$ & $2.13^{2}$ \\
\hline \multicolumn{4}{|l|}{ Orthoptera } \\
\hline Tettigonidae NI & $8.33(7)$ & $0.71(10)$ & $9.60^{1}$ \\
\hline Acrididae NI & $10.71(9)$ & $0.99(14)$ & $3.63^{1}$ \\
\hline Grasshoppers \& Bush Crickets NI & $7.14(6)$ & $0.64(9)$ & $4.96^{1}$ \\
\hline \multicolumn{4}{|l|}{ Gryllotalpidae } \\
\hline Gryllotalpa sp. & $3.57(3)$ & $0.21(3)$ & $10.50^{1}$ \\
\hline TOTAL Orthoptera & $25.00(21)$ & $2.54(36)$ & 28.69 \\
\hline \multicolumn{4}{|l|}{ Hemiptera (Suborder Heteroptera) } \\
\hline Hemiptera NI & $20.24(17)$ & $1.27(18)$ & $5.40^{3}$ \\
\hline \multicolumn{4}{|l|}{ Hymenoptera } \\
\hline Formicidae NI & $11.90(10)$ & $2.19(31)$ & $0.31^{2}$ \\
\hline Hymenoptera $\mathrm{n} /$ formicidae NI & $11.90(10)$ & $4.23(60)$ & --- \\
\hline TOTAL Hymenoptera & $21.43(18)$ & $6.42(91)$ & --- \\
\hline \multicolumn{4}{|l|}{ Lepidoptera } \\
\hline Lepidoptera NI & $1.19(1)$ & $0.07(1)$ & --- \\
\hline \multicolumn{4}{|l|}{ Coleoptera } \\
\hline Cantharidae NI & $1.19(1)$ & $0.07(1)$ & --- \\
\hline \multicolumn{4}{|l|}{ Scarabaeidae } \\
\hline \multicolumn{4}{|l|}{ Scarabaeinae } \\
\hline Copris hispanicus & $1.19(1)$ & $0.07(1)$ & $0.25^{1}$ \\
\hline Onitis ion & $14.29(12)$ & $1.69(24)$ & $2.00^{1}$ \\
\hline Onitis belial & $29.76(25)$ & $4.66(66)$ & $35.11^{1}$ \\
\hline Cheironitis sp. & $4.76(4)$ & $0.28(4)$ & $0.66^{1}$ \\
\hline Bubas sp. & $38.10(32)$ & $6.21(88)$ & $19.24^{1}$ \\
\hline
\end{tabular}

This article is protected by copyright. All rights reserved. 
Onthophagus sp.

Aphodinae

Aphodius sp.

Melolonthinae

Amphimallon nigrum

Rhizotrogus sp.

Cetoniinae

Cetoniinae NI

Protaetia sp.

Tropinota sp.

Oxythyrea sp.

Chrysomelidae

Chrysolina bankii

Geotrupidae

Geotrupes sp.

Carabidae

Carabidae NI

Chlaenius velutinus

Carabus sp.

Curculionidae

Curculionidae NI

Tenebrionidae

Tenebrionidae NI

Alphasida sp.

Sepidium sp.

Buprestidae

Capnodis tenebricosa

Silphidae

Silpha sp.

Staphylinidae

Staphylinidae NI

Ocypus olens

Histeridae

Histeridae NI

TOTAL Coleoptera

Diptera

Asilidae NI

\section{CHORDATA}

REPTILIA

Squamata

Squamata NI

OTHER

Bird egg shell

Falco naumanni
$15.48(13) \quad 1.06(15)$

$0.15^{4}$

$13.10(11) \quad 1.69(24) \quad 0.14^{1}$

$40.48(34) \quad 25.44(360) \quad 34.20^{1}$

$1.19(1) \quad 0.07(1) \quad 0.04^{2}$

$\begin{array}{ccc}13.10(11) & 1.13(16) & --- \\ 9.52(8) & 0.78(11) & 2.50^{1} \\ 20.24(17) & 1.69(24) & --- \\ 5.95(5) & 0.35(5) & ---\end{array}$

$39.29(33)$

$9.88(140)$

$8.54^{1}$

$1.19(1) \quad 0.07(1)$

$35.71(30)$

$8.62(122)$

$9.28^{1}$

$1.19(1) \quad 0.07(1) \quad 0.20^{2}$

$11.90(10)$

$0.78(11)$

$2.75^{1}$

$19.05(16) \quad 1.48(21) \quad 1.19^{1}$

$10.71(9) \quad 1.06(15) \quad 0.73^{1}$

$16.67(14) \quad 1.62(23)$

$25.00(21) \quad 2.40(34) \quad 3.90^{1}$

$5.95(5) \quad 0.49(7) \quad 0.75^{1}$

$36.90(31) \quad 4.02(57) \quad 3.81^{1}$

$3.57(3) \quad 0.21(3) \quad--$

$25.00(21) \quad 6.07(86)$

$7.14(6) \quad 0.56(8)$

$98.81(83) \quad 82.61(1169)$

$1.19(1) \quad 0.21(3)$

\begin{tabular}{llll} 
Falco naumanni & $2.38(2)$ & $0.14(2)$ & --- \\
\hline
\end{tabular}

Biomass data sources: ${ }^{1}$ - this study, ${ }^{2}$ - Gameiro 2015, ${ }^{3}$ - Rodríguez et al. 2010, ${ }^{4}$ - Orłowski and Karg 2011.

This article is protected by copyright. All rights reserved. 
Table 3. Diet composition ( $\mathrm{NF}=$ frequency of occurrence) of European Roller nestlings based on video recording of nest provisioning at Castro Verde, southern Portugal ( $\mathrm{n}=19$ nests); NI = non-identified.

\begin{tabular}{|c|c|}
\hline PHYLUM/CLASS/Order/Family/Subfamily & NF (\%) \\
\hline \multicolumn{2}{|l|}{ MOLLUSCA } \\
\hline \multicolumn{2}{|l|}{ GASTROPODA } \\
\hline Gastropoda NI & $1.16(4)$ \\
\hline \multicolumn{2}{|l|}{ ARTHROPODA } \\
\hline \multicolumn{2}{|l|}{ ARACHNIDA } \\
\hline Arachnidae NI & $0.29(1)$ \\
\hline \multicolumn{2}{|l|}{ INSECTA } \\
\hline Orthoptera & $74.20(256)$ \\
\hline Acrididae NI & $35.94(124)$ \\
\hline Tettigoniidae NI & $20.87(72)$ \\
\hline Grasshopers \& bush crickets NI & $17.39(60)$ \\
\hline \multicolumn{2}{|l|}{ Lepidoptera } \\
\hline Lepidoptera NI & $0.58(2)$ \\
\hline \multicolumn{2}{|l|}{ Coleoptera } \\
\hline Coleoptera NI & $7.54(26)$ \\
\hline \multicolumn{2}{|l|}{ Mantodea } \\
\hline Mantodea NI & $0.29(1)$ \\
\hline \multicolumn{2}{|l|}{ CHILOPODA } \\
\hline \multicolumn{2}{|l|}{ Scolopendromorpha } \\
\hline \multicolumn{2}{|l|}{ Scolopendridae } \\
\hline Scolopendra sp. & $1.16(4)$ \\
\hline \multicolumn{2}{|l|}{ CHORDATA } \\
\hline \multicolumn{2}{|l|}{ REPTILIA } \\
\hline \multicolumn{2}{|l|}{ Squamata } \\
\hline \multicolumn{2}{|l|}{ Scincidae } \\
\hline Chalcides sp. & $0.58(2)$ \\
\hline \multicolumn{2}{|l|}{ OTHER } \\
\hline Bird egg shell & $2.03(7)$ \\
\hline NON-ORTHOPTERA UNIDENTIFIED & $12.17(42)$ \\
\hline TOTAL PREY & 345 \\
\hline
\end{tabular}

This article is protected by copyright. All rights reserved. 
Table 4. Isotopic niches of adult and nestling European Rollers as measured by Bayesian standard ellipse areas (SEA , with $95 \%$ credible intervals) and sample size-corrected standard ellipse areas $\left(\mathrm{SEA}_{\mathrm{C}}\right)$. Niche overlap, expressed as the proportion of $\mathrm{SEA}_{\mathrm{C}}$ of one group overlapped by its pair (males and females and vice-versa, adults and chicks and vice-versa) is presented for each group. Samples sizes for each group are given in parenthesis.

\begin{tabular}{lccc}
\hline & SEA $_{B}$ & SEA $_{C}$ & Niche overlap \\
\hline Males (15) & $0.610[0.372-1.094]$ & 0.647 & 1.0 \\
Females (20) & $0.816[0.495-1.291]$ & 1.110 & 0.58 \\
All adults (35) & $0.672[0.471-0.950]$ & 0.877 & 0 \\
Chicks (15) & $0.440[0.266-0.765]$ & 0.714 & 0 \\
\hline
\end{tabular}

This article is protected by copyright. All rights reserved. 